Article

\title{
Livelihoods on the Edge without a Safety Net: The Case of Smallholder Crop Farming in North-Central Namibia
}

\author{
Dian Spear * and Angela Chappel \\ African Climate \& Development Initiative, 6th floor Geological Sciences Building, University Avenue South, \\ University of Cape Town, Rondebosch, Cape Town 7700, South Africa; chappelangela@gmail.com \\ * Correspondence: dian.spear@uct.ac.za; Tel.: +27-21-6502838
}

Received: 24 May 2018; Accepted: 15 June 2018; Published: 21 June 2018

\begin{abstract}
Semi-arid Namibia is marginal for agricultural production. Low soil fertility combined with low and variable rainfall restrict the livelihoods of smallholder farmers who often struggle to produce enough food. Although historically, communities have adopted a number of coping mechanisms, climate change threatens to further reduce agricultural production. There are many additional options available to smallholder farmers to adapt to climate change, but they are not necessarily adopting these measures despite having noticed increasing temperatures and declining rainfall. Semi-structured interviews were conducted in three villages in Onesi constituency to examine what agricultural practices smallholder crop farmers use, perception of changes in their yields, their perspective on future yields and whether they are planning on changing their agricultural practices. The results suggest that to sustain the livelihoods of rural communities in north-central Namibia, support is needed from local and regional authorities, as well as traditional and religious leaders to assist with enhancing access to information, enabling information sharing on adaptation options, and increasing awareness on climate change, its impacts and what can be done about it. In addition to this, implementation of the adaptation action also requires demonstration sites and building capacity to enable the development of self-help groups.
\end{abstract}

Keywords: vulnerability; culture; religion; agency; adaptation; perceptions; climate change; dependency

\section{Introduction}

Semi-arid environments are becoming increasingly harsh for smallholder farmers. This means that providing a livelihood is becoming even more difficult. By their nature, semi-arid lands are difficult to eke out a living in. They are remote, infertile, have limited services and have variable climates, although they are generally hot and dry [1,2] This makes surviving on agriculture difficult. However, communities in these environments have managed in the past by adopting different coping mechanisms. North-central Namibia is no exception. In this marginal environment, agriculture has persisted by people adopting ways of coping with uncertain rainfall. One of the traditional Ovambo farming practices is the use of indigenous land units with different elevation and soil characteristics to plant different crops under different climatic conditions [3].

More recently, a number of other mechanisms have been used by some farmers to sustain their livelihoods. These include: (i) diversifying livelihoods to off-farm activities [3,4]; (ii) growing drought-resistant crop varieties such as early maturing Okashana millet with a three-month growing season [5]; (iii) keeping heat-resistant breeds of livestock [6]; (iv) adjusting planting of crops by delaying, using a combination of early and late planting, and/or planting multiple times within a season $[7,8](\mathrm{v})$ soil and water conservation through conservation tillage, ripping, ridging, farrowing, 
crop rotation, intercropping and the use of manure [6]; (vi) supplemental feeding, watering and moving to access alternative water and grazing resources for livestock $[3,6]$ and sometimes selling livestock [3]; (vii) storing mahang $u$ [3] and getting food from friends and neighbours [3]; (viii) receiving remittances from family members living in urban areas [4]; and (ix) relying on pension grants from the government [3,9]. However, in drylands although remote communities can be well equipped to cope with climate variability and change, they are often marginalized, chronically disadvantaged, and can battle to secure resources to respond to changes in climate [10].

Despite the different measures available to cope with variable climates, not all farmers can or do apply these measures, e.g., there is limited crop and livelihood diversification [3] and many of the existing crops and livestock are susceptible to drought, heat stress and disease. Livestock owners also often don't sell livestock when there is impending drought [11] and crops and livestock losses are most often not insured [12]. As a consequence of this reliance on rain-fed crops and livestock for livelihoods, and a lack of alternatives, these communities are sensitive to climate variability and change $[3,11]$. In addition, as food insecurity is getting worse, some coping measures, such as the sharing of food, are becoming less prominent [3].

Inherent poverty, marginalization and inequality [13], degraded natural resources [14], limited availability of fertile land, [6] and limited grazing [3,6,14] combined with unreliable crop yields, mean that many households face food insecurity, which is most pronounced during drought periods [11]. Droughts are already becoming more frequent and intense and this trend is expected to worsen in the future. Significant increases in temperature have been observed in Namibia over the past century [15], and there has been a decrease in average annual rainfall [16] with higher variability in rainfall and more droughts since 1970 [17], but also frequent floods [18]. Of concern is that trends of increased temperatures and reduced rainfall are expected to continue in north-central Namibia $[7,19,20]$ and as such, agricultural productivity is expected to decrease [21].

Although smallholder farmers have already noticed reductions in rainfall and increases in temperature [9] and have experienced severe droughts that have led to major crop and livestock losses, they are not necessarily changing their agricultural practices $[7,22]$. This qualitative study uses three villages in Onesi constituency in the Omusati region of Namibia as a case study to examine: (i) the agricultural practices that smallholder crop farmers use; (ii) the perceptions of these farmers of changes in their yields; (iii) their perceptions about the future and what their planned responses are; and (iv) barriers to the adoption of new agricultural practices.

\section{Materials and Methods}

The study was conducted in three villages in the Onesi constituency in Omusati region in semi-arid north-central Namibia. 31 structured interviews were conducted across the villages: Okathitukeengombe $(n=10)$, Omaenene $(n=11)$ and Oshihau $(n=10)$, by Angela Chappel (AC) between 4 and 15 July 2017. The secretary of the Uukolonkadhi traditional authority set up a meeting with each village headman who granted permission for interviews to be conducted in their respective villages. The headmen also identified a few initial interviewees, after which snowball sampling was used to locate others. The sample was $68 \%$ female compared to $55 \%$ female in the 2011 census for Onesi constituency [23]. The mean age of the sample was 56; 55\% of interviewees were between 26 and 59 and $45 \%$ were over 60 years old. In the 2011 census, the equivalent figures would be $83 \%$ in the age group of 15 to 59 and $17 \%$ in the age group [23]. Although the sample was largely aged and female, these were the people who were home and looking after the crops. In this paper, quotes are given from 17 of the farmers (10 females and 7 males).

A translator assisted in asking farmers, in the local language of Oshiwambo, about their agricultural practices, whether they think their yields have changed over time, whether they think there will be future changes in their yields, if they are worried about their future food supply, what changes they have made or plan to make to their farming practices and what prevents them from making these changes. During the interviews, the translator loosely translated each answer given by the respondent. 
This allowed AC to understand the essence of the interview and to ask further questions where necessary for clarification. Interviews were recorded using a Dictaphone and after the interviews, $\mathrm{AC}$ and the translator listened to the recordings and transcribed each interview into English so that all information was captured, and quotes could be recorded word for word. The interview data was then coded for different themes taking note of relevant quotes. The identity of the interviewees was also coded. As some of the data on barriers to adopting agricultural practices is published elsewhere, [24] summary information is presented in the results for barriers to adopting new practices.

\section{Results}

\subsection{Livelihoods in the Study Area}

During interviews with the 31 respondents (ten men and 22 women) it was noted that generally when a family owned livestock, men were responsible for the livestock and women were responsible for crop production. If the family did not own livestock, crop production responsibilities tended to be shared. In terms of the use of crop yields, 20 respondents used their crops for subsistence only and 11 sold certain of their crops or homemade sorghum beer when they had adequately supplied their own family and had an excess of yields. Mahangu (pearl millet) $(n=30)$, cowpeas $(n=30)$, and sorghum $(n=27)$ were the most commonly grown crops. Other crops that are grown included maize, watermelon, Bambara nuts, cooking melons, ground nuts, pumpkins, and oilseed melons. In addition to these crops, some families had fruit trees either around their homestead or in the fields with their crops. The fruit trees grown across the study site are lemon, mango, marula, guava, palm, and custard apple.

\subsection{Smallholder Farmer Perceptions of Past Changes}

Most crop farmers in this study mentioned that the soil quality of their fields and their crop yields have declined over time. One farmer explained that their "family has been living here for more than 50 years and the texture of the soil is changing, and nutrients are decreasing" (FK28). Another farmer said, "When I first came here, I used to get much better yields" (FM82). The most commonly stated reason for observed changes in yields was that rainfall in the area has decreased: "It has also changed because of rain, because sometimes you will plough your field and sow seeds, but the rain won't come or when it comes it is just not enough for the crops, and this results in dry land which leads to poor yield" (MM73). Next most mentioned was the depletion of nutrients from the soil due to overuse followed by soil erosion. A farmer mentioned that "the land lost nutrients because the rain washed it away" (FS89). The weather was also blamed for low yields: "Last year was hotter and drier than this year, so we received less yield than this year" (MK30). Crickets were also held responsible by five farmers. One farmer explained that "the crickets came this year and decreased the yield" (FS48). Two people also mentioned that their soil is nutrient poor because they do not have livestock: "The nutrients are depleted because we keep using the same land every year and we don't have livestock to put manure on the land" (FK70). A lack of animals, after them having died in the drought, was also linked to poor yields by them not being available for ploughing and having to use a tractor instead. One farmer said: "Now we use a tractor, but I believe the tractor brings bad soil to the top and puts the good soil deep into the ground" (MM60).

\subsection{Farming Approaches That Have Been Applied by Smallholder Crop Farmers}

Many farmers still use indigenous land units and plant different crops in different portions of land; they also intercrop some of the crops and rotate some. One farmer mentioned they "look at the soil structure and nutrients and plant different crops in different portions" (FS45) and another that they "grow each crop in a different portion and change them every year" (FK62). However, different farmers intercrop different crops. One famer mentioned "Bambara nuts and sorghum have their own portion" (MK30), another that they "intercrop sorghum, mahangu, oilseed melons and cooking 
melons" (MK30); yet another said that "different portions for maize, Bambara, sorghum; other crops are intercropped" (FK70).

Farmers also move crops between land units if they don't do well during periods of climatic variability. One farmer explained that, "when the sorghum doesn't do well we put mahangu and watermelon, then move the sorghum to grow somewhere else" (FK40). Another said, "where we put mahangu, if it doesn't do well, the next year we plant it somewhere else and plant Bambara nuts there" (FK26). The use of drought resistant varieties is also common. One farmer mentioned, "I have changed the mahangu I usually grow (Ongonga) to Kangara and Okashana \#2. Ongonga takes long to mature, so it requires the rain to start early but now rain starts very late, while Kangara and Okashana mature faster, if the rain comes late, we will be able to get a better yield" (MM72). However, different varieties are used in wet years. Another farmer said that, "when there is too much rainfall I change the variety from Okashana \#2 to Kangara. When there is too much rainfall Kangara is better because it can withstand the water better and Okashana falls. But the problem is that Kangara does not mature fast enough so this year while we were waiting for it to grow the crickets came and killed the crops" (FS40). Another response to changes in yields by many farmers is the application of manure. One farmer explained, "We apply the manure from the livestock to replace the nutrients" (MM68).

Despite some of the approaches mentioned above, some farmers were of the opinion that they have not changed any of their farming approaches, despite having noticed declines in their yields. One famer mentioned, "We have not changed any crops or techniques. We don't have animals to put manure on the land" (FS89). However, another farmer said, "I have never changed the farming practices or crops because I don't know any other ways" (FK85).

\subsection{Smallholder Perceptions of the Future and Their Planned Responses}

In general, the smallholder farmers do not perceive reduced yields in the future. Many $(n=11)$ farmers mention that their yields depend on rain but don't seem to have any opinion of rainfall trends in the future. One farmer indicated, "If it rains we will get a good yield, if it doesn't rain the yield will be bad" (FK37). Quite a few farmers $(n=5)$ thought their yields would improve in future because of crop rotation or applying manure. One farmer thought "yields might get better in the future because even this year was better than last year, and this might continue if we keep rotating crops" (FK26). Another was of the opinion that "the yield will get better because we put manure everywhere, if it rains the soil quality will improve and we will get better yields" (FS45). However, 12 farmers mentioned an expected decline in yields for a number of different reasons. Some thought their yields would decline because of low soil fertility. One farmer thought that "the yield will be less in the future because the nutrients will keep being depleted and the soil will get worse" (FK70). Another perspective was that crickets would reduce yields. One farmer thought "the yields will get worse because of the crickets" (FS40). A few farmers did not know, and a few were of the opinion that only God knew. One farmer explained, "We don't know how the crop yield will change in future, because we haven't been receiving good rainfall in the past but when it came this year, it was too much again that it ended up flooding our fields killing our crops. So, if anybody says she/he thinks the yield will be high or low in future that person must be lying, no one can predict the future, only God knows" (MM73). Only one farmer mentioned that because of climate change there might be reduced yields in the future. This young farmer explained that, "according to climate change if there is too much rain or not enough rain the yields will be poor. I can't predict what will happen, but I think that there will probably be less rain" (FK28).

Some farmers perceived that they would still be able to provide for themselves in the future using the same approaches as now. One farmer thought that "with crop rotation we will get a good enough yield to supply food for our family. New variety Okashana \#2 will also help us-we will get this from Ministry of Agriculture" (MK75). Others didn't what know what will happen in the future or trusted in God to provide for the future. The minority opinion was that there would not be enough food in the future. One man mentioned: "I don't think we will have enough food for the family in the future 
because having bad land with no nutrients and poor rainfall is going to lead to poor yields and not enough food" (FK78).

Twenty-four of the farmers were worried about food security in the future. Some said that they were worried because they were not sure it would rain, others were worried because the land was not very fertile, and some were not worried because they had faith in God. One farmer mentioned: "I am very worried. The land has poor nutrients which is bad for growing crops. We can't predict rainfall anymore and we don't know when it will come. In the past we used to predict rainfall. Now even if you predict rain you will be surprised that you don't get rain" (FK78). However, seven farmers we not worried about the future. This was predominantly attributed to faith that God will provide sufficient rain or that the government will provide assistance. One farmer's perspective was that he was "not worried because we don't know what God has in store for us. He is the creator, he will provide" (MS42). The same farmer also expected that the government would provide food for them if they were going hungry: "There is no other method that I can use in my field because we don't have enough water. Maybe I will get enough food for my family but if I don't, the government will assist us" (MS42). Another mentioned, "We are even thinking that the government should help us with projects that will give us food" (MM72). Although many of the farmers perceived that their crop output would in fact decrease in the future, bar one, all respondents said that they would continue farming in the same way without adaptation. Only one farmer (MM68) was preparing for the future and he had recently attended a workshop on adaptation. When asked specifically about climate change, 16 respondents stated that they had heard about climate change either on the radio, by word of mouth, or from school. Most of the respondents believed that climate change would cause decreased rainfall in the future.

\subsection{Barriers to Changing Farming Practices}

Most farmers said they would continue to farm their crops in the same way as now. Many mentioned tradition as a reason for this. One farmer mentioned that "we are used to farming in the same way" (FK70). Another farmer mentioned that they do not have another option. Whereas others mentioned they might try something else if they had information on it. One farmer said, "we just have to continue farming the same way because we don't have any other information on the other methods that we could possibly use, and our animals have died of drought we will continue using tractors" (MM72). When asked specifically whether farmers would adopt new practices, they expressed willingness to do so but there were barriers to doing so. The most commonly mentioned barrier was lack of information on new or alternative farming practices followed by a belief that current approaches are the only or best way. Other popular responses were that farmers feared new approaches would not work or that they did not have enough water. Other than this money, equipment, time, labour and old age were mentioned as reasons.

\section{Discussion}

Perceptions of vulnerability and future risk play an important role in adaptation to climate change $[25,26]$ and action to respond is shaped by belief systems, personal experiences and perceived responsibility of the problem $[25,27,28]$. In this study, climate change did not specifically come up as a contributing factor to reducing yields nor did farmers express a perception of worsening droughts. Although climatic change may be difficult for farmers to detect amidst the climatic variability that is characteristic of drylands $[29,30]$ this result perhaps also reflects on a lack of awareness about climate change. Despite the likelihood that yields are going to decline in the future because of the expected effects of climate change [21], the smallholder farmers that were interviewed did not reflect this in their responses. The factors that were mentioned as affecting yields were those that would be expected for agriculture: rain, soil fertility, the weather, crickets, and the availability of livestock for ploughing and providing manure. However, the tendency for farmers to have a stronger memory of more recent events e.g., crickets and short-term trends should also be taken into consideration [31]. 
Although some farmers are worried about soil fertility and are uncertain about having enough rain in the future, the findings of this study suggest that many smallholder farmers in north-central Namibia may not be aware of how vulnerable they are to climate change. As such, they are not necessarily expecting changing conditions in future and are not planning for this by changing their approach to securing food for their families. The coping mechanisms that were mentioned as being already used by farmers were the use of land units, intercropping, and crop rotation, but farmers did not consider that as changing their practices and did not plan to change practices despite reductions in yields. These findings are in concordance with other studies that have also suggested that if farmers are not aware that they are vulnerable to the effects of climate change they will be less likely to respond e.g., in rural communities in Brazil [32].

It is expected that if farmers perceive the effects of climate change to be imminent they will take action to adapt [33]. Fortunately, there are examples of where this is so e.g., in Tanzania where farmers perceived increasing temperatures and decreasing rainfall, they changed to drought-resistant crops and increased the area under cultivation to make up for declining yields [34]. Similarly, farmers in Kenya that noticed similar trends in temperature and rainfall started mulching and planting early maturing crops [35]. In Kenya, there are also examples of farmers adopting new approaches, e.g., rice farming, after perceiving the land as being degraded [36]. However, farmers do not always respond to perceived changes. For example, a study in South Africa showed that $95 \%$ of farmers perceived changes in temperature and $97 \%$ perceived changes in rainfall, yet $62 \%$ of the farmers did not adapt in any way to these changes [37]. Similarly, although farmers perceive changes in north-central Namibia, they are not necessarily changing their agricultural practices.

Some farmers in north-central Namibia are not worried about the future because they believe that God will provide or that the government will assist them if they do not have enough food. Others are not willing to change because of traditional norms. In north-central Namibia, culture is a central component of Oshiwambo people's lives and farming traditions [22]. This is very important to take into consideration here as it can act as a barrier to adaptation when those who prescribe to it are bound to cultural practices that have been passed down over many generations and are unwilling to deviate from what is known and trusted $[27,38]$. Such cognitive and normative social barriers to climate change adaptation are widely recognised [39-41]. Mindsets influenced by traditional norms, religious beliefs and dependence on government, make smallholder farmers more vulnerable to impending climate change and are important to consider because the perception of risk is more important than calculated estimations of risk in determining response behaviour [27]. Farmers are also less likely to adopt climate smart agricultural practices if they are skeptical about climate change [38] and they are likely to be less aware and have a limited understanding of climate change if they have a low level of education $[30,31]$.

A number of factors have likely led to high vulnerability and low levels of agency that are currently seen in north-central Namibia. A history of colonial dispossession, market-driven economic policies, and gender inequality has led to chronic poverty, marginalization and inequality in the country [13]. In addition, there is a culture of expectancy of the government to do something. The government has been providing social grants including state pensions as well as drought relief and people are very reliant on this. This situation of government assistance reducing adaptive capacity is also seen in other remote drylands in Botswana and Australia and is considered potentially maladaptive [10]. However, it should be recognised that some form of social protection is needed to keep people out of extreme poverty and food insecurity. In Namibia, drought relief could be maladaptive in that it is encouraging the continuation of existing activities, creating dependency and reducing the use of coping mechanisms and further innovation. Importantly, Namibians could learn lessons from other countries where innovative agricultural practices have been used to combat the effects of climate change. For example, in Ghana, many farmers say that they are not concerned by environmental change because they innovate using methods such as zai pits and trash lines, intercropping, use of manure, and tied-ridges [42]. 
Despite there being a number of different possible coping mechanisms and adaptation options that could be employed, many of these are not used in north-central Namibia. There are a number of reasons for this. Some of the barriers to action, such as lack of information, traditional norms, religious beliefs (the expectation that God will provide) and a reliance on government, influence perceptions and others impede the implementation of adaptation interventions e.g., lack of water, money, equipment, time, labour and old age [24].

The problem of limited information on adaptation solutions is frequently cited as the main barrier to the adoption of new agricultural practices in Namibia [22,43], and elsewhere e.g., South Africa [37]. Scientific information is crucial in helping smallholder farmers e.g., to establish early warning systems and change the time of planting [44]; insufficient information is a problem not only at the farmer level, but also with extension officers and higher levels of authority $[7,45,46]$. It has been previously noted that there is limited awareness about climate change and its impacts, in addition to a lack of knowledge about solutions [7,45]. Part of the problem is that climate change information and technical advice is not being interpreted and communicated to policy makers, practitioners and farmers to assist with decision making [45-47]. In addition, many farmers don't have access to extension services in north-central Namibia $[43,48]$

The provision of information and enhanced knowledge through education, training, and communication is a vital component of changing behaviour and initiating action [49]. Therefore, to sustain the livelihoods of rural communities in north-central Namibia support is needed from local and regional authorities, as well as traditional and religious leaders to assist with enhancing access to information, enabling information sharing on adaptation options, and increasing awareness on climate change, its impacts and what can be done about it. In addition, the implementation of adaptation action also requires beneficial interventions such as demonstration sites and building capacity to enable the development of self-help groups.

It is important that information is framed appropriately to take into consideration local traditional and religious beliefs and that it is communicated by someone that is trusted by the community [24, 38,50]. Therefore, it is important to work with community leaders that are informed about climate change, its impacts and what can be done about it so that they are able to share information that is context relevant [50]. In north-central Namibia, radio is an important avenue for communicating this information as most households have radios [46].

Although having information is useful, it has been found that more action happens (e.g., investment in research and training of extension services) when actors see the benefits of an intervention e.g., agroforestry improving food security in Zambia [51]. Some farmers will only adopt new practices after witnessing success by others, even when they are aware of the benefits e.g., of compost [52]. Both demonstration sites [46] and working with champions [24] are an opportunity for communities to observe effective practices e.g., the demonstration of planting pits near a busy road in Burkina Faso [53].

Having enough labour is also often vital to enable the adoption of some labour-intensive practices and can be achieved through self-help groups [54-56], in which farmers organise themselves to take turns working on each other's farms e.g., in Ethiopia [56]. These can also strengthen social networks, which are important in the uptake of soil and water conservation practices as an essential means of sharing information, brainstorming ideas and as an informal source of credit $[37,57]$. Rural development policies that promote the formation of formal or informal farmer associations can strengthen this form of farmer-to-farmer interaction $[55,58]$.

\section{Conclusions}

This study indicates that the lack of understanding of future risks posed by climate change is problematic. If smallholder farmers do not perceive that they are vulnerable or becoming more vulnerable, they have less motivation to change. Having said this, another study [3] indicated that farmers in focus groups in Omusati region, mentioned concern over being able to continue farming if there was an increase in dry years. However, there are many other reasons they might not change as 
evidenced through the findings. It is not merely a case of a lack of access to finances [7], limited access to technologies such as drought resistant seed [59] or the time, labour and effort required. Local norms, customs and beliefs influence adaptation to climate change by influencing conceptual understanding of the reason for hazards as well as whether people decide to make changes to minimize current and future risks $[25,28]$. This study shows both how traditional norms and religious beliefs are preventing people from making changes, thereby making them more vulnerable to climate change. But it is not only the intent to continue with traditional farming practices and faith that God will provide that make these communities vulnerable. Another reason why smallholder farmers do not necessarily do anything to change their practices is the expectation that the government will do something to help. All of these ways of thinking prevent action by these smallholder farmers.

For communities in these drylands to sustain livelihoods in these areas, they need to adopt more climate-smart agricultural practices and they need access to alternative livelihoods. Part of the solution is building the adaptive capacity of these communities so that they can help themselves. In other developing countries, often where there isn't as much state support, there is a stronger presence of self-help groups, self-mobilisation self-organisation, and innovation [60] e.g., women's self-help groups in India [61]. The attitude of waiting for God or the government to resolve the situation isn't useful when it is expected that conditions are going to get much worse and food security will decrease. Although there are limited resources in villages in north-central Namibia, a change in perspective would help in bringing forth action. It is hoped that traditional leaders and religious leaders can play a role in changing some of these perspectives.

Although suggestions are being made here on how to increase the adaptive capacity of rural farmers in northern Namibia, it cannot be said that the government does not have some measures in place. There are some government agricultural projects in existence. One of these is the FAO (Food and Agriculture Organisation) and EU (European Union) funded MAWF (Ministry of Agriculture, Water and Forestry) Learning and Information Sharing for Agriculture SMS (Short Message Service) line, where farmers can communicate with extension officers [62]. It would be beneficial if this innovative platform for information sharing could be further promoted e.g., through radio [46]. However, it would also be beneficial for smallholder farmers to have more access to extension services, especially where there is no radio and cellular phone network. These communities need agricultural support, but they also need training and access to markets to enable them to diversify their livelihoods outside of agriculture.

Author Contributions: D.S. and A.C. conceptualized the study, A.C. collected and analysed the data under the supervision of D.S. and D.S. wrote the manuscript based on A.C.'s thesis.

Funding: This research was funded by International Development Research Centre grant number 107640-001 and Department of Science and Technology, Republic of South Africa grant number 0123/2014.

Acknowledgments: Efaishe Kavela is thanked for translating. This work was carried out under the Adaptation at Scale in Semi-Arid Regions project (ASSAR). ASSAR is one of four research programmes funded under the Collaborative Adaptation Research Initiative in Africa and Asia (CARIAA), with financial support from the UK Government's Department for International Development (DfID) and the International Development Research Centre (IDRC), Canada. The views expressed in this work are those of the creators and do not necessarily represent those of DfID and IDRC or its Board of Governors. This work was also funded by the South African Department of Science and Technology.

Conflicts of Interest: The authors declare no conflict of interest.

\section{References}

1. Reynolds, J.F.; Smith, D.M.S.; Lambin, E.F.; Turner, B.L.; Mortimore, M.; Batterbury, S.P.; Downing, T.E.; Dowlatabadi, H.; Fernández, R.J.; Herrick, J.E.; et al. Global desertification: Building a science for dryland development. Science 2007, 316, 847-851. [CrossRef] [PubMed]

2. Sietz, D.; Ludeke, M.K.B.; Walther, C. Categorisation of typical vulnerability patterns in global drylands. Glob. Environ. Chang. 2011, 21, 431-440. [CrossRef] 
3. Newsham, A.J.; Thomas, D. Agricultural Adaptation, Local Knowledge and Livelihood Diversification in North-Central Namibia; Research Technical Report; Tyndall Climate Change Research Centre: Norwich, UK, 2009; pp. 1-48.

4. Angula, M. Gender and Climate Change: Namibia Case Study; Heinrich Boell Foundation: Cape Town, South Africa, 2010; p. 45.

5. Uno, D. Farmer's selection of local and improved pearl millet varieties in Ovamboland, Northern Namibia. Afr. Study Monogr. 2005, 30, 107-117.

6. Kuvare, U.; Maharero, T.; Kamupingene, G. Research on Farming Systems Change to Enable Adaptation to Climate Change; University of Namibia for the Ministry of Environment and Tourism and the United Nations Development Program Namibia: Windhoek, Namibia, 2008; p. 103.

7. Dirkx, E.; Hager, C.; Tadross, M.; Bethune, S.; Curtis, B. Climate Change Vulnerability and Adaptation Assessment: Namibia; Desert Research Foundation of Namibia and Climate Systems Analysis Group for the Ministry of Environment and Tourism: Windhoek, Namibia, 2008; p. 149.

8. Government of the Republic of Namibia. Third National Communication to the United Nations Framework Convention on Climate Change; Ministry of Environment and Tourism: Windhoek, Namibia, 2015; p. 173.

9. Angula, M.N.; Kaundjua, M.B. The changing climate and human vulnerability in north-central Namibia. Jamba J. Disaster Risk Stud. 2016, 8, 1-7. [CrossRef]

10. Maru, Y.T.; Smith, M.S.; Sparrow, A.; Pinho, P.F.; Dube, O.P. A linked vulnerability and resilience framework for adaptation pathways in remote disadvantaged communities. Glob. Environ. Chang. 2014, 28, 337-350. [CrossRef]

11. Muhangi, P.; Acidri, J. North Central Namibia Upland Cereal and Livestock Zone, Upland Cereal and Non-Farm Income Zone: Baseline Livelihood Profiles; Livelihoods Assessment Main Report; Office of the Prime Minister-Directorate Emergency Management: Windhoek, Namibia, 2008; p. 32.

12. Zeidler, J.; Kandjinga, L.; David, A. Study on the Effects of Climate Change in the Cuvelai Etosha Basin and Possible Adaptation Measures; Integrated Environmental Consultants Namibia: Windhoek, Namibia, 2010; p. 34.

13. Jauch, H.; Edwards, L.; Cupido, B. Inequality in Namibia. In Tearing Us Apart: Inequalities in Southern Africa; Jauch, H., Muchena, D., Eds.; Open Society for Southern Africa: Johannesburg, South Africa, 2011; pp. 181-255.

14. Klintenberg, P.; Seely, M.; Christiansson, C. Local and national perceptions of environmental change in central Northern Namibia: Do they correspond? J. Arid Environ. 2007, 69, 506-525. [CrossRef]

15. Hulme, M.; Doherty, R.; Ngara, T.; New, M.; Lister, D. African climate change: 1900-2100. Clim. Res. 2001, 17, 145-168. [CrossRef]

16. Hutchinson, P. Notes on the Namibia Volumetric Annual Rainfall; Namibia Meteorological Services: Windhoek, Namibia, 1998.

17. Intergovernmental Panel on Climate Change (IPCC). Climate Change 2007: Impacts, Adaptation and Vulnerability; Summary for Policymakers. Working Group II Contribution to the Intergovernmental Panel on Climate Change Fourth Assessment Report; Cambridge University Press: Cambridge, UK, 2007; p. 44.

18. Gilau, A.M.; Dayo, F.B.; Abraham, L.Z.; Mundia, L. Drought and Flood Risk Assessment Tool for Gender Specific Decision-Making; Summary Report; Triple “E” Systems Inc, USA for Africa Adaptation Project-Namibia. Republic of Namibia: Windhoek, Namibia, 2011; pp. 1-30.

19. Davis, C.L. Climate Risk and Vulnerability: A Handbook for Southern Africa; Council for Scientific and Industrial Research: Pretoria, South Africa, 2011; p. 92.

20. Department of Environmental Affairs. Long-Term Adaptation Scenarios Flagship Research Programme for South Africa (LTAS) Phase 1. Climate Trends and Scenarios for South Africa Technical Report (no. 1 of 6). Pretoria, South Africa. 2013. Available online: https://www.environment.gov.za/sites/default/files/docs / climate_trends_bookV3.pdf (accessed on 20 June 2018).

21. Intergovernmental Panel on Climate Change. Climate Change 2014: Impacts, Adaptation, and Vulnerability, Part A: Global and Sectoral Aspects; Contribution of Working Group II to the Fifth Assessment Report; Cambridge University Press: Cambridge, UK, 2014; p. 1132.

22. Von Hase, F. Facilitating Conservation Agriculture in Namibia through Understanding Farmers' Planned Behaviour and Decision Making; Swedish University of Agricultural Sciences: Upsalla, Sweden, 2013; p. 62.

23. Namibia Statistics Agency Namibia 2011: Population and Housing Census Main Report; Namibia Statistics Agency: Windhoek, Namibia, 2011; p. 212. 
24. Davies, J.; Spear, D.; Chappel, A.; Joshi, N.; Togarepi, C.; Kunamwene, I. Considering religion and tradition in Climate Smart Agriculture: Insights from Namibia. In The Climate-Smart Agriculture Papers: Investigating the Business of a Productive, Resilient and Low Emission Future; Rosenstock, T., Nowak, A., Girvetz, E., Eds.; Springer International Publishing: Basel, Switzerland, in press.

25. Schipper, E.L.F. Religion as an integral part of determining and reducing climate change and disaster risk: An agenda for research. In Climate Change: The Social Science Perspective; Voss, M., Ed.; VS-Verlag: Wiesbaden, Germany, 2010; pp. 377-392. ISBN 978-3-531-15925-6.

26. Balama, C.; Augustino, S.; Eriksen, S.; Makonda, F. Forest adjacent households' voices on their perceptions and adaptation strategies to climate change in Kilombero District, Tanzania. SpringerPlus 2016, 5, 792. [CrossRef] [PubMed]

27. Becken, S.; Lama, A.; Espiner, S. The cultural context of climate change impacts: Perceptions among community members in the Annapurna Conservation Area, Nepal. Environ. Dev. 2013, 8, 22-37. [CrossRef]

28. Thomalla, F.; Smith, R.; Schipper, L. Cultural aspects of risk to environmental changes and hazards: A review of perspectives. In Disasters' Impact on Livelihood and Cultural Survival: Losses, Opportunities, and Mitigation; Companion, M., Ed.; CRC Press: Boca Raton, FL, USA, 2015; pp. 3-18.

29. Slegers, M.F.W. "If only it would rain": Farmers' perceptions of rainfall and drought in semi-arid central Tanzania. J. Arid Environ. 2008, 72, 2106-2123. [CrossRef]

30. Gbetibouo, G.A. Understanding Farmers' Perceptions and Adaptations to Climate Change and Variability: The Case of the Limpopo Basin, South Africa; Environment and Production Technology Division Discussion Paper 00849; International Food Policy Research Institute: Washington, DC, USA, 2009; p. 52.

31. Muller, C.; Shackleton, S. Perceptions of climate change and barriers to adaptation amongst commonage and commercial livestock farmers in the semi-arid Eastern Cape Karoo. Afr. J. Range Forage Sci. 2014, 31, 1-12. [CrossRef]

32. Da Silva-Rosa, T.; Bonatti, M.; Vanini, A.; Zuffo, C. Vulnerability and climate change perceptions: A case study in Brazilian biomes. Environ. Pollut. 2014, 3, 82-96. [CrossRef]

33. Alam, G.M.M.; Alam, K.; Mushtaq, S. Climate change perceptions and local adaptation strategies of hazard-prone rural households in Bangladesh. Clim. Risk Manag. 2017, 17, 52-63. [CrossRef]

34. Mongi, H.; Majule, A.E.; Lyimo, J.G. Vulnerability and adaptation of rainfed agriculture to climate change and variability in semi-arid Tanzania. Afr. J. Environ. Sci. Technol. 2010, 4, 371-381. Available online: http:/ / www.academicjournals.org/AJEST.

35. Ogalleh, S.A.; Vogl, C.R.; Eitzinger, J.; Hauser, M. Local perceptions and responses to climate change and variability: The case of Laikipia District, Kenya. Sustainability 2012, 4, 3302-3325. [CrossRef]

36. Gicheru, M. Barriers and Enablers to Uptake and Implementation of System of Rice Intensification: A Case Study of Mwea Irrigation Scheme in Kenya. Master's Thesis, University of Cape Town, Cape Town, South Africa, 2016. Available online: http:/ / hdl.handle.net/11427/23716 (accessed on 20 June 2018).

37. Bryan, E.; Deressa, T.T.; Gbetibouo, G.A.; Ringler, C. Adaptation to climate change in Ethiopia and South Africa: Options and constraints. Environ. Sci. Policy 2009, 12, 413-426. [CrossRef]

38. Gruère, G.; Wreford, A. Overcoming Barriers to the Adoption of Climate-Friendly Practices in Agriculture; OECD Food, Agriculture and Fisheries Papers, No. 101; OECD Publishing: Paris, France, 2017; p. 40.

39. Adger, W.N.; Dessai, S.; Goulden, M.; Hulme, M.; Lorenzoni, I.; Nelson, D.R.; Naess, L.; Wolf, J.; Wreford, A. Are there social limits to adaptation to climate change? Clim. Chang. 2009, 93, 335-354. [CrossRef]

40. Biesbroek, G.R.; Klostermann, J.E.M.; Termeer, C.J.A.M.; Kabat, P. On the nature of barriers to climate change adaptation. Reg. Environ. Chang. 2013, 13, 1119-1129. [CrossRef]

41. Shackleton, S.; Ziervogel, G.; Sallu, S.; Gill, T.; Tschakert, P. Why is socially-just climate change adaptation in sub-Saharan Africa so challenging? A review of barriers identified from empirical cases. WIREs Clim. Chang. 2015, 6, 321-344. [CrossRef]

42. Nyantakyi-Frimpong, H.; Bezner-Kerr, R. The relative importance of climate change in the context of multiple stressors in semi-arid Ghana. Glob. Environ. Chang. 2015, 32, 40-56. [CrossRef]

43. Paulus, N.N. Factors Affecting Subsistence Farmers' Adoption of Sustainable Land Management Practices in Oshikoto Region, Namibia; United Nations University Land Restoration Training Programme: Reykjavik, Iceland, 2015.

44. Antwi-Agyei, P.; Dougill, A.J.; Stringer, L.C. Barriers to climate change adaptation: Evidence from northeast Ghana in the context of a systematic literature review. Clim. Dev. 2015, 7, 297-309. [CrossRef] 
45. Ministry of Environment and Tourism. Namibia Second National Communication on Climate Change to the United Nations Framework Convention on Climate Change; Ministry of Environment and Tourism: Windhoek, Namibia, 2011; p. 125.

46. Thomas, B. An assessment of the role of research and extension services for small-scale crop farmers in North-Central Namibia. J. Agric. Biodivers. Res. 2012, 1, 122-126. Available online: http://www. onlineresearchjournals.org/JABR (accessed on 20 June 2018).

47. David, A.; Braby, J.; Zeidler, J.; Kandjinga, L.; Ndokosho, J. Building adaptive capacity in rural Namibia: Community information toolkits on climate change. Int. J. Clim. Chang. Strateg. Manag. 2013, 5, 215-229. [CrossRef]

48. Jona, C.N.; Terblanche, S.E. Farmers' perception on contact frequency, adequacy, relevance and quality of agriculture support services in Oshikoto region in Namibia. S. Afr. J. Agric. Ext. 2015, 43, 107-121.

49. Michie, S.; van Stralen, M.M.; West, R. The behaviour change wheel: A new method for characterizing and designing behaviour change interventions. Implement. Sci. 2011, 6, 42. Available online: http://www. implementationscience.com/content/6/1/42 (accessed on 20 June 2018). [CrossRef] [PubMed]

50. Nyasimi, M.; Kimeli, P.; Sayula, G.; Radeny, M.; Kinyangi, J.; Mungai, C. Adoption and Dissemination Pathways for Climate-Smart Agriculture Technologies and Practices for Climate-Resilient Livelihoods in Lushoto, Northeast Tanzania. Climate 2017, 5, 63. [CrossRef]

51. Garrity, D.P.; Akinnifesi, F.K.; Ajayi, O.C.; Weldesemayat, S.G.; Mowo, J.G.; Kalinganire, A.; Larwanou, M.; Bayala, J. Evergreen Agriculture: A robust approach to sustainable food security in Africa. Food Secur. 2010, 2, 197-214. [CrossRef]

52. Ouédraogo, E.; Mando, A.; Zombré, N.P. Use of compost to improve soil properties and crop productivity under low input agricultural system in West Africa. Agric. Ecosyst. Environ. 2001, 84, 259-266. [CrossRef]

53. Danjuma, M.N.; Mohammed, S. Zai Pits System: A catalyst for restoration in the dry lands. J. Agric. Vet. Sci. 2015, 8, 1-4. [CrossRef]

54. Critchley, W.; Graham, O. Looking after Our Land: Soil and Water Conservation in Dryland Africa; Oxfam Publishing: London, UK, 1991; p. 88.

55. Nkegbe, P.K.; Shankar, B.; Ceddia, G. Smallholder adoption of soil and water conservation practices in northern Ghana. In Proceedings of the EAAE 2011 Congress: Change and Uncertainty Challenges for Agriculture, Food and Natural Resources, Zurich, Switzerland, 30 August-2 September 2011; p. 13.

56. Sidibé, A. Farm-level adoption of soil and water conservation techniques in northern Burkina Faso. Agric. Water Manag. 2005, 71, 211-224. [CrossRef]

57. Sietz, D.; Van Dijk, H. Land-based adaptation to global change: What drives soil and water conservation in western Africa? Glob. Environ. Chang. 2015, 33, 131-141. [CrossRef]

58. Nganga, S.K.; van Wijk, M.T.; Rufino, M.C.; Giller, K.E. Adaptation of agriculture to climate change in Ethiopia. Reg. Environ. Chang. 2016, 16, 2317-2330. [CrossRef]

59. Office of the Prime Minister-Directorate Emergency Management. Namibia Rural Food and Livelihood Security Vulnerability Assessment and Analysis Report 2014/2015; Government of the Republic of Namibia: Windhoek, Namibia, 2014; p. 23.

60. Adger, W.N. Social capital, collective action, and adaptation to climate change. Econ. Geogr. 2003, 79, 387-404. [CrossRef]

61. Reddy, C.S.; Manak, S. 2005 Self-Help Groups: A Keystone of Microfinance in India-Women Empowerment and Social Security; Mahila Abhivruddhi Society: Hyderabad, India.

62. Ministry of Agriculture, Water and Forestry, Learning and Information Sharing for Agriculture. Available online: http:/ / www.lisa.com.na/admin/ (accessed on 22 May 2018).

(C) 2018 by the authors. Licensee MDPI, Basel, Switzerland. This article is an open access article distributed under the terms and conditions of the Creative Commons Attribution (CC BY) license (http:/ / creativecommons.org/licenses/by/4.0/). 